\title{
Relationships Between Strains of Mycoplasma mycoides subspp. mycoides and capri Studied by Two-dimensional Gel Electrophoresis of Cell Proteins
}

\author{
By A. W. RODWELL AND E. SHIRLEY RODWELL \\ C.S.I.R.O. Division of Animal Health, Animal Health Research Laboratory, \\ Private Bag No. 1, P.O. Parkville, Victoria, Australia 3052
}

(Received 22 March 1978)

\begin{abstract}
Strains of Mycoplasma mycoides subsp. mycoides have been divided into small colony (SC) and large colony (LC) types (Cottew \& Yeats, 1978). The protein patterns of representative strains of these two types and of $M$. mycoides subsp. capri were compared by a high resolution, two-dimensional gel electrophoretic method. The results suggest that the LC strains are more closely related to $M$. mycoides subsp. capri than to the SC strains of $M$. mycoides subsp. mycoides.
\end{abstract}

\section{INTRODUCTION}

The separation of Mycoplasma mycoides into the subspecies mycoides and capri rests solely on the nature of their carbohydrate antigenic determinants: the former subspecies synthesizes a polysaccharide having 6-O- $\beta$-linked D-galactofuranoside determinants (Buttery, 1970) and the latter, a glucan (Jones et al., 1965). Cottew \& Yeats (1978) have separated the subsp. mycoides into two types on the basis of growth rate, colony size and other characteristics. Strains of the organism of bovine pleuropneumonia and a few strains isolated from goats are of the slower-growing small colony (SC) type. The faster-growing large colony (LC) type are mostly strains isolated from goats.

Organisms of the LC type resemble those of $M$. mycoides subsp. capri by the criteria of Cottew \& Yeats (1978), and also in their propensity for growth in the $\rho$-form (Rodwell et al., 1973). Under appropriate conditions $\rho$-forms were abundant in all recently isolated strains of the LC type and also of the subsp. capri but were not found in SC strains. Thus, apart from the difference in antigenic determinants, strains of the LC type resemble the capri subsp. rather than SC strains. Hence it was of interest to examine the phylogenetic relationships between the two subspecies by other means.

In this paper we compare the protein 'fingerprints' of representative strains by a high resolution, two-dimensional gel electrophoretic method. We conclude that strains of the LC type are more closely related to $M$. mycoides subsp. capri than to the SC type of $M$. mycoides subsp. mycoides.

\section{METHODS}

Mycoplasma strains. The strains and their classification are shown in Table 1. Apart from strain $\mathrm{H}_{22 / 1 \mathrm{f}}$, the subsp. mycoides strains were those used by Cottew \& Yeats (1978) in reaching their criteria for subdivision into SC and LC types. Of the SC strains, PG1 (type strain for the mycoides subsp.), V5, Gladysdale and $\mathrm{KH}_{3} \mathrm{~J}$ were from cattle and the $\mathrm{O}, \mathrm{P}$ and Vom strains were from goats. Of the LC strains, $\mathrm{H}_{22 / \mathrm{jf}}$ is a $\rho$-form mycoplasma with the characteristics of the LC type which was isolated after enrichment by serial subculture of the V5 strain in a partly defined medium (Rodwell et al., 1972); strain 801 was isolated from the eye of a cow and the other strains were from goats. PG3 is the type strain for the capri subsp., while 5907A and 5357L were isolated in Australia from goats (Littlejohns \& Cottew, 1977). 
Growth of organisms. The growth medium (pH 7.8) contained: PPLO broth base without crystal violet (Difco), $2.1 \%(\mathrm{w} / \mathrm{v})$; Albimi yeast autolysate (Pfizer), 0.6\% (w/v); DNA (calf thymus), 0.002\% (w/v); sodium phosphate, $0.05 \mathrm{M}$; glucose, $0.04 \mathrm{M}$; ox serum, $10 \%(\mathrm{v} / \mathrm{v})$. The medium was sterilized by filtration thrcugh Seitz pads.

The organisms were grown in $5 \mathrm{ml}$ portions of medium containing $\left[\mathrm{U}-{ }^{14} \mathrm{C}\right.$ ]protein hydrolysate $(2 \cdot 5 \mu \mathrm{Ci}$ $\mathrm{ml}^{-1}$ ) and harvested in the late-exponential or early-stationary phase of growth as determined by absorbance at $650 \mathrm{~nm}$. The cells were washed once in $5 \mathrm{ml}$ of a solution containing $0 \cdot 15 \mathrm{M}$-sodium phosphate, $10 \mathrm{~mm}$ $\mathrm{MgSO}_{4}$ and $1 \%(\mathrm{w} / \mathrm{v})$ Casamino acids (Difco) at $\mathrm{pH} \mathrm{7.0.} \mathrm{The} \mathrm{yield} \mathrm{of} \mathrm{protein} \mathrm{varied} \mathrm{from} 0.25$ to $0.5 \mathrm{mg}$ for the SC strains and from 1.0 to $2.0 \mathrm{mg}$ for the LC and subsp. capri strains.

Two-dimensional gel electrophoresis. Two-dimensional gel electrophoresis was carried out by the method of $\mathrm{O}^{\circ}$ Farrell (1975) in which proteins are separated in the first dimension by isoelectric focusing in gel cylinders and in the second dimension by sodium dodecyl sulphate-gel electrophoresis in gel slabs, with modifications to improve the solubilization and focusing of proteins in the first dimension. The modified electrophoretic method and the method used for sample preparation have been described (Archer et al., 1978). Samples applied to the isoelectric focusing gels contained $25000 \mathrm{~d} . \mathrm{p.m}$. of radioactivity and about $20 \mu \mathrm{g}$ protein. The volume of the samples varied from 10 to $25 \mu \mathrm{l}$. The resolving gel for SDS-gel electrophoresis in the second dimension contained a uniform $12 \%(\mathrm{w} / \mathrm{v})$ concentration of acrylamide. The protein spots were detected by the fiuorographic method of Bonner \& Laskey (1974) as modified by Laskey \& Mills (1975).

Comparison of protein patterns. Comparison of the protein patterns between pairs of strains was facilitated by using positive copies of the fluorograms in which the protein spots appeared as translucent spots on a dark background. The positive copy of the fluorogram for one strain was placed over that of another and the common spots were marked on the top film. The positive copies were then interchanged, top to bottom, and the common spots were marked on the new top film. The numbers of marked spots and the total number of spots on each film were used to determine the percentage congruence between the two patterns (Table 1).

\section{RESULTS AND DISCUSSION}

The type strains for the subspp. mycoides and capri are PGI and PG3, respectively. Strain $\mathrm{Y}$ was selected as a standard strain for the LC type of the mycoides subsp. Fluorograms of these three strains after exposure at $-70^{\circ} \mathrm{C}$ for $10 \mathrm{~d}$ (Fig. $1 a, b$ and $c$ ) contained 132,142 and 154 spots, respectively. After an optimum exposure of about $20 \mathrm{~d}$, approximately 300 individual spots were counted on fluorograms of strains of $M$. mycoides. This represents about half of the expected coding capacity of the genome. Autoradiographic spreading of spots during prolonged exposure is a major factor limiting resolution: minor spots lying close to major ones may be engulfed before they can be detected. Where we saw a series of spots on the same horizontal ordinate but of similar pI values we interpreted this as an example of charge heterogeneity of a single protein. An example can be seen in Fig. 1(a) at the coordinates (horizontal $\times$ vertical) $49 \times 14$. Charge heterogeneity may be induced in vivo by post-transcriptional modification of proteins or in vitro during sample preparation and analysis (O'Farrell, 1975).

All cultures of the LC strains of the mycoides subsp. and of the capri subsp. contained a high proportion of $\rho$-forms (Peterson et al., 1973). Protein B, the protein of which the $\rho$-fibre is composed (Rodwell et al., 1975), is located at the coordinates $65 \times 85,70 \times 74$ and $70 \times 85$ in Fig. $1(b, c$ and $d)$, respectively. Protein A, located at the coordinates $60 \times 27$ and $65 \times 25$ in Fig. $1(b$ and $d$ ), respectively, is a major, membrane-associated protein (Rodwell $e t$ al., 1975) which is present in most, but not all, strains of $M$. mycoides subsp. mycoides of the LC type and of subsp. capri (Rodwell et al., 1973). It was not synthesized by any of the SC strains.

The percentage congruence of protein pattern between the various strains and each of the three standard strains was determined on fluorograms exposed for $4 \mathrm{~d}$, because the task of matching spots was easier with the less complex patterns and the smaller spots. The total number of spots counted on the films ranged from 70 to 120 . In some cases the percentage congruence was also determined using fluorograms exposed for $30 \mathrm{~d}$. These results were similar to those obtained after the shorter exposure. Although the patterns showed excellent agreement between replicate analyses, the absolute positions of the spots varied slightly. 

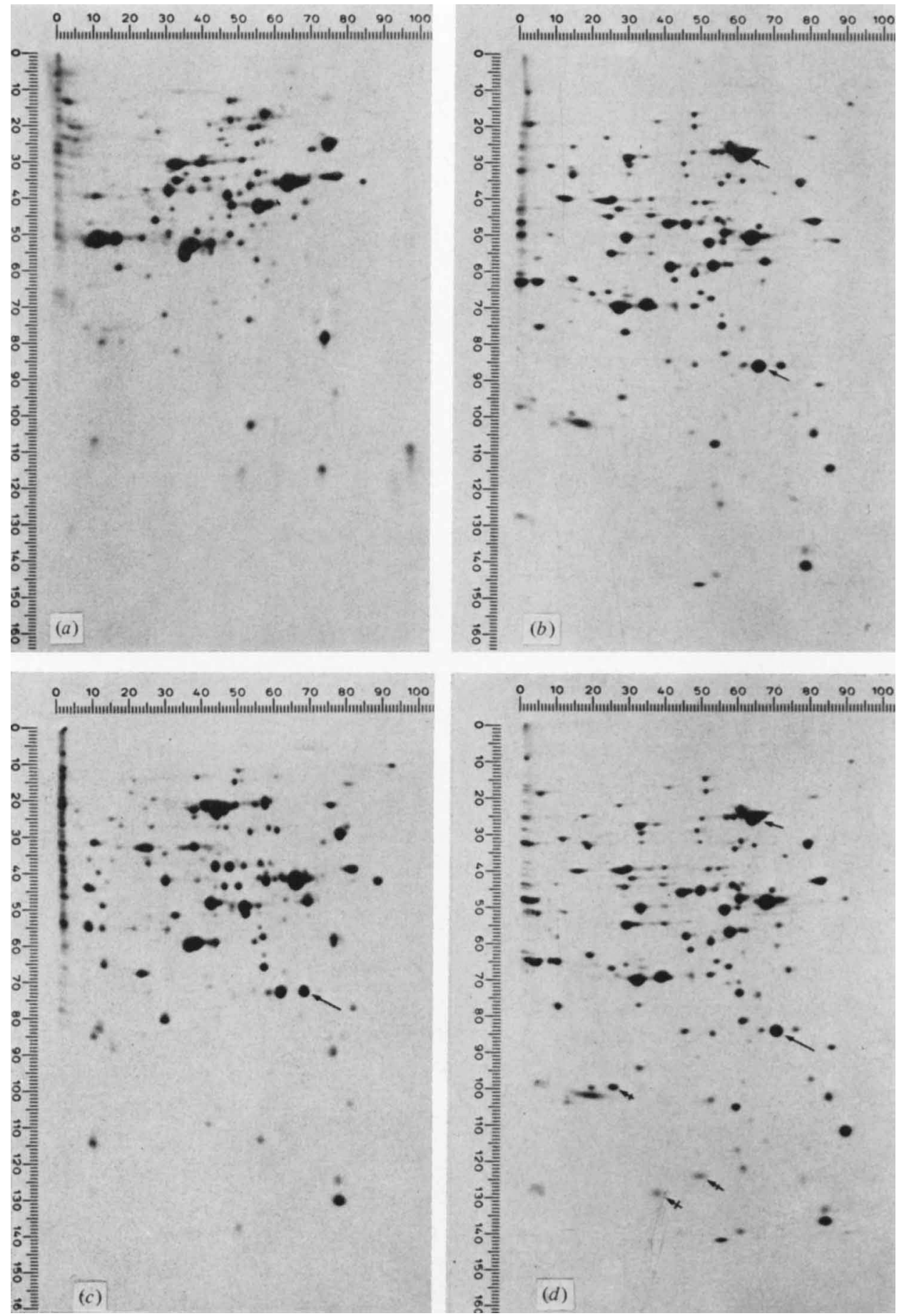

Fig. 1. Protein patterns of Mycoplasma mycoides strains: (a) PG1, (b) Y, (c) PG3, (d) 801. Fluorograms were exposed at $-70^{\circ} \mathrm{C}$ for $10 \mathrm{~d}$. Horizontal ordinate, first dimension by isoelectric focusing (IEF); vertical ordinate, second dimension by SDS-gel electrophoresis. Samples were applied to the IEF gels at the cathode (left). A small amount of protein (5 to $10 \%$ ) failed to enter the IEF gels and appears as a vertical streak in the second dimension. Spots are located by the intersection of the horizontal and vertical coordinates, the scales being in millimetres on the original fluorograms. Spots referred to in the text are indicated by arrows or crossed arrows. 
Table 1. Percentage congruence* of protein patterns between the standard strains and other strains of Mycoplasma mycoides subspp. mycoides and capri

\begin{tabular}{|c|c|c|c|}
\hline \multirow[b]{2}{*}{ Strain } & \multicolumn{3}{|c|}{ Standard strain } \\
\hline & PG1 & $\mathbf{Y}$ & PG3 \\
\hline \multicolumn{4}{|c|}{ subsp. mycoides SC type $\dagger$} \\
\hline PG1 & - & $<10$ & $<10$ \\
\hline V5 & 83 & $<10$ & $<10$ \\
\hline Gladysdale & 78 & $<10$ & $<10$ \\
\hline $\mathbf{K H}_{\mathbf{3}} \mathbf{J}$ & 82 & $<10$ & $<10$ \\
\hline $\mathrm{O}$ & 67 & $<10$ & $<10$ \\
\hline $\mathbf{P}$ & 58 & $<10$ & $<10$ \\
\hline Vom & 79 & $<10$ & $<10$ \\
\hline \multicolumn{4}{|c|}{ subsp. mycoides LC type +} \\
\hline $\mathrm{Y}$ & $<10$ & - & 26 \\
\hline $\mathrm{H}_{22 / 1 \mathrm{f}}$ & $<10$ & 100 & 27 \\
\hline $801^{1 / 2}$ & $<10$ & 99 & 26 \\
\hline OSB42 & $<10$ & 45 & 18 \\
\hline KH1 & $<10$ & 60 & 29 \\
\hline Ojol & $<10$ & 40 & 30 \\
\hline Ojo2 & $<10$ & 50 & 41 \\
\hline $74 / 2488$ & $<10$ & 63 & 30 \\
\hline $\operatorname{Cov}$ & $<10$ & 31 & 39 \\
\hline \multicolumn{4}{|l|}{ subsp. capri } \\
\hline PG3 & $<10$ & 26 & - \\
\hline $5907 \mathrm{~A}$ & $<10$ & 33 & 47 \\
\hline $5357 \mathrm{~L}$ & $<10$ & 37 & 40 \\
\hline
\end{tabular}

* Percentage congruence was calculated as $\left[2 N_{\mathrm{AB}} /\left(N_{\mathrm{A}}+N_{\mathrm{B}}\right)\right] \times 100$, where $N_{\mathrm{A}}$ and $N_{\mathrm{B}}$ were the total numbers of spots on the fluorograms for strains $\mathrm{A}$ and $\mathrm{B}$, and $N_{\mathrm{AB}}$ was the number of spots common to both. † Small colony (SC) and large colony (LC) types (Cottew \& Yeats, 1978).

Thus, when spots in different areas of the fluorograms were being matched it was necessary to move one film relative to the other over distances of a few millimetres. Matching of spots was governed by pattern recognition, i.e. by the position of the spot relative to its neighbours and by spot size and shape, and where any two strains had enough protein pattern in common, spots could be matched with confidence. When the SC strains were compared with strains Y or PG3, and when the LC strains or subsp. capri strains were compared with PG1, there was insufficient pattern in common to make spot-matching possible. The value (less than $10 \%$ ) assigned for the congruence of pattern in these comparisons represents an upper limit and congruence may well be much lower.

The results (Table 1) showed:

(i) There was a significant congruence between the protein patterns of the strains within each of the three groups and their respective standard strains, whereas congruence could not be shown between the protein patterns of the SC strains and strains Y or PG3, or between the LC and subsp. capri strains and PGl.

(ii) A congruence of pattern ranging from 18 to $41 \%$ was found between the LC strains and PG3, and from 26 to $37 \%$ between the subsp. capri strains and strain Y. The strain Cov occupied an intermediate position, its protein pattern being a little more closely related to PG3 than to strain Y.

(iii) The protein patterns of strains $\mathrm{Y}$ and $\mathrm{H}_{22 / 11}$ were identical, even after exposure for $30 \mathrm{~d}$. Thus our earlier suggestion (Rodwell et al., 1972) that the $\rho$-form strain $\mathrm{H}_{22 / 1 \mathrm{f}}$ was a variant derived from the V5 strain cannot be correct: strain $\mathrm{H}_{22 / 1 \mathrm{t}}$ could not possibly have been derived by short-term mutation and selection from the V5 strain and must have originated by cross-contamination of a culture of V5, probably with strain Y. As a consequence 
of its faster growth rate in the partly-defined medium, the contaminant would have then been enriched by serial subculture and isolated after cloning.

(iv) Strain 801 is very closely related to, but not identical with strain Y (congruence of pattern $99 \%$ ). It synthesized three proteins (indicated by crossed arrows in Fig. $1 d$ ) which were absent from the fluorograms of strain Y, even after exposure for $30 \mathrm{~d}$ (cf. Fig. $1 b$ and d). A spot congruent with a fourth spot at the coordinates $74 \times 68$ (Fig. $1 d$ ) was present on the fluorogram of strain $\mathrm{Y}$ after exposure for $30 \mathrm{~d}$, but was undetectable after exposure for $10 \mathrm{~d}$ (Fig. 1 b). Strain 801 is the only strain of bovine origin in the LC group. It seems unlikely, although the possibility cannot be excluded, that it could have originated from the $Y$ strain in the laboratory. It was of the LC type, at least with respect to colony size and growth rate, when first isolated from the eye of a cow which had been inoculated subcutaneously with the SC strain $\mathrm{KH}_{3} \mathrm{~J}$ (J. R. Etheridge, personal communication). The protein pattern of strain 801 was quite different from that of $\mathrm{KH}_{3} \mathrm{~J}$.

In interpreting the protein patterns of different strains we assume that congruent spots are composed of isofunctional proteins of identical, or nearly identical, amino acid sequence. Isoelectric focusing is potentially capable of resolving proteins differing by a single charge. Isofunctional proteins with extensive amino acid sequence homology may be resolved by the two-dimensional electrophoretic method and classed as distinct and unrelated proteins, and therefore strains which are indistinguishable by DNA hybridization methods may have large differences in protein patterns. A comparison of protein 'fingerprints' is a powerful tool for distinguishing between closely related strains or between mutants of the same strain. The method is particularly well suited to study the proteins of mycoplasmas. Because of the limited size of their genome, the protein 'fingerprints' of mycoplasmas are relatively less complex and are more readily interpretable than those of other micro-organisms.

We conclude that the LC strains are more closely related to $M$. mycoides subsp. capri than to the SC strains of $M$. mycoides subsp. mycoides, and that neither the subsp. capri nor the LC strains are closely related to the SC strains of $M$. mycoides subsp. mycoides.

We are indebted to the Wellcome Trust for providing a grant.

\section{REFERENCES}

ARCHER, D. B., RoDWell, A. W. \& RoDWELl, E. S. (1978). The nature and location of Acholeplasma laidlawii membrane proteins investigated by twodimensional gel electrophoresis. Biochimica et biophysica acta (in the Press).

BONNER, W. M. \& LASKeY, R. A. (1974). A film detection method for tritium-labelled proteins and nucleic acids in polyacrylamide gels. European Journal of Biochemistry 46, 83-88.

ButTERY, S. H. (1970). Hapten inhibition of the reaction between Mycoplasma mycoides polysaccharide and bovine antisera. Immunochemistry 7, 305-310.

Cottew, G. S. \& Yeats, F. R. (1978). Subdivision of Mycoplasma mycoides subsp. mycoides from cattle and goats into two types. Australian Veterinary Journal 54, 293-296.

Jones, A. S., Tittensor, J. R. \& Walker, R. T. (1965). The chemical composition of the nucleic acids and other macromolecular constituents of Mycoplasma mycoides var. capri. Journal of General Microbiology 40, 405-411.

LASKeY, R. A. \& MILLS, A. D. (1975). Quantitative film detection of ${ }^{3} \mathrm{H}$ and ${ }^{14} \mathrm{C}$ in polyacrylamide gels by fluorography. European Journal of Biochemistry 56, 335-341.
Littlejohns, I. R. \& Cottew, G.S. (1977). The isolation and identification of Mycoplasma mycoides subsp. capri from goats in Australia. Australian Veterinary Journal 53, 297-298.

O'Farrell, P. H. (1975). High resolution twodimensional electrophoresis of proteins. Journal of Biological Chemistry 250, 4007-4021.

Peterson, J. E., Rodwell, A. W. \& Rodwell, E. S. (1973). Occurrence and ultrastructure of a variant ( $r h o$ ) form of Mycoplasma. Journal of Bacteriology 115, 411-425.

Rodwell, A. W., Peterson, J. E. \& Rodwell, E. S. (1972). Macromolecular synthesis and growth of mycoplasmas. In Pathogenic Mycoplasmas: a Ciba Foundation Symposium, pp. 123-144. Amsterdam: Associated Scientific Publishers.

Rodwell, A. W., Peterson, J. E. \& Rodwell, E. S. (1973). Nature of striated structures in mycoplasmas. Annals of the New York Academy of Sciences 225, 190-200.

Rodwell, A. W., Peterson, J. E. \& Rodwell, E. S. (1975). Striated fibers of the rho form of $\mathrm{Myco-}$ plasma: in vitro reassembly, composition, and structure. Journal of Bacteriology 122, 1216-1229. 